\title{
Redesigning Poverty Alleviation Organization in Kendari
}

\author{
Joko Tri Brata \\ Sulawesi Tenggara University of Kendari - Indonesia \\ Email: joko_tribrata@yahoo.co.id
}

Doi:10.5296/ jpag.v5i3.8078 URL: http://dx.doi.org/10.5296/ jpag.v5i3.8078

\begin{abstract}
Poverty is a classical problem which needs organizational redesign in order to refresh, and renew the organization. This can be done by optimizing resources unification in each organization through innovation of organizational management and functions and renewal of the values shaping bureaucrats (referred to by Jokowi as Mental Revolution). This research aims at describing institutional model application and applying new institutional model (redesign) for the sustainability of poverty alleviation policy in Kendari. This is a qualitative research with experimental approach using developmental research pattern. The research describes that the application of institutional model in poverty alleviation in Kendari which is integrated in TKPKD is merely formal institutional setting and is assumed to have conventional framework. The attempt of applying organizational new design of poverty alleviation can be done by preparing the organization through institutional model improvement by optimizing the potentials of program correlated fields.
\end{abstract}

Keywords: Redesigning Organization, Poverty Alleviation 


\section{Introduction}

The Presidential Decree Number 15 Year 2010 defines poverty as urgent national problem which needs systematic, integrated, and wholistic treatment and approaches. Poverty has been viewed differently from many aspects based on its perspective (Djatnika, 2009). Based on the data from Bappenas as stated by Woro S. Sulistyaningrum, since 2010, there has been slowing process of poverty reduction although totally it can decrease around 1 million poor people per year. The level of poverty in March 2013 was around 11,37\% or 28,07 million people. This number was 0,59 million people lower than that in 2012 (RKP target was around RKP 2014 of $9,5 \%-10,5 \%)$.

Meanwhile, the data from Bappenas also states contradictory data where around $55,7 \%$ poor people in 2009 has been alleviated from their poverty by 2010. On the contrary, however, there were other groups which do not belong to poor level of society in 2009 that was 21,52\% RTHM, 11,54\% RTHTM, and 2,94\% RTTM who became poor in 2010.

The coordination of poverty alleviation program is done by forming Poverty Alleviation Coordinating Team (TKPK) based on Indonesian Presidential Decree Number 54 Year 2005, which is revised by Presidential decree Number 13 year 2009, and is currently revised by Presidential Decree Number 15 Year 2010 on Acceleration of poverty Alleeviation aiming at actively taking role in doing concrete actions to speed up poverty reduction in Indonesian national territory. This can be done through coordination which involves synchronization, harmonization, and integrity of many poverty alleviation programs and activities.

Presidential Decree Number 15 year 2010 aslo regulates the formulation of Local Poverty Alleviation Coordinating Team (TKPKD) in the provincial level and Regency/City. The team involves cross sectoral team and cross stakeholders at the provincial level, Regency, and City where the institutional structure and work mechanism of TKPK is regulated by the Domestic Affair Ministerial Decree Number 42 year 2010. Meanwhile, in Kendari they form Local Poverty Alleviation Coordinating Team Organization of Kendari (TKPKD) based on Majorial decree Number 598 Year 2011.

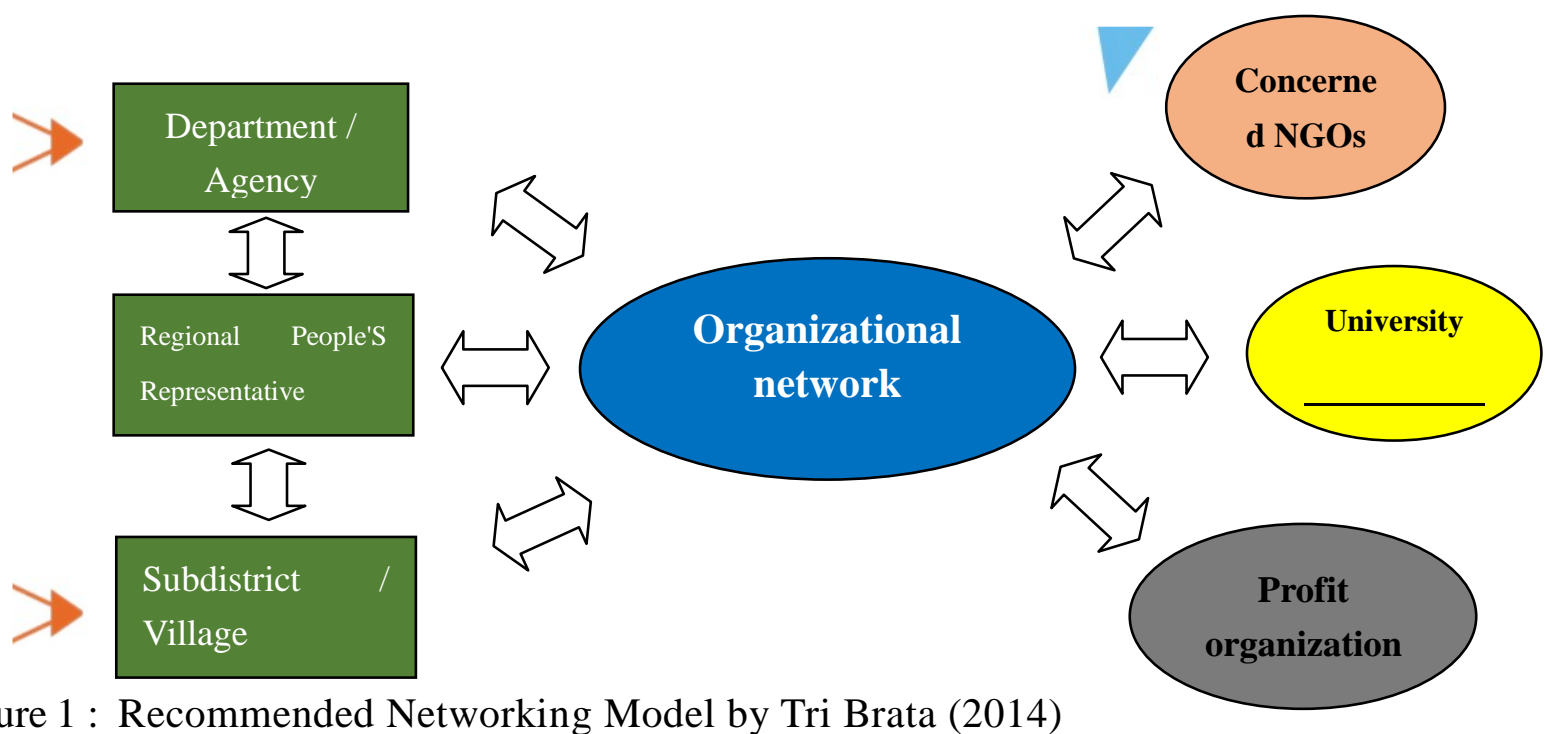

Figure 1: Recommended Networking Model by Tri Brata (2014) 


\section{MInstitute Macrothink}

Journal of Public Administration and Governance

ISSN 2161-7104

2015, Vol. 5, No. 3

The figure above is recommended by the previous researcher, Tri Brata (2014). It states that one of the concepts which can be applied is cross organizational networking in which there are many organizations with the same necessity and goal involved. In the concept of poverty alleviation it is no longer appropriate to approach it only economically, but it needs to be approached with new approach namely networking approach for prosperity. This approach highlights the needs to optimize resources unification in each organization which is collaborated in certain order for prosperity by doing some institutional innovations (Tri Brata, 2014).

\section{Analysis}

Presidential Decree Number 15 Year 2010 regulates the formation of Local Poverty Alleviation Coordinating Team (TKPKD) at the provincial level and Regency or City which becomes the only organization formed by the government to coordinate poverty alleviation at the local level (see page 2). In the institutional context of TKPKD currently, the research shows the fact that TKPKD applies hierarchical model and that those involved in the organization only serve as formal institutional setting so that for the context of organizational effectivity TKPKD needs organizational networking (Tri Brata, 2014). Therefore, Rulinawaty (2015) states that the focus of organizational success is through strengthening integrated organization (or networking) which sets as the main factor in organization development, including by strengthening society through social empowerment (Tri Barat, 2015).

The same notion is also stated by Asiah Hamsah (2012) that since 1996, Chinese government has established special institution to alleviate poverty at the central and local level which is referred to as Leading Group Office for Poverty Reduction (LGPR). It is also proven that innovative model on the basis of collaboration (or networking) is an appropriate model to solve the needs, problem, and social aspiration (Ramadhan, 2015).

Goldsmith (2009) states that the profit of networking model is the sustainability of specialization, innovation, swiftness, flexibility, and range widening. In the networking context, it is stated that activities of the parties in the networking organization related to program implementation is highly beneficial in the attempt of attaining collective goal. The institution plays role to focus on how the organization shape the behaviour of actors. This kind of institutional model is signed with innovative pattern applied in the local context (Tri Brata, 2014).

\section{Organizational Redesigning Approach}

Organizational redesign is an attempt to redesign the organization by putting force on the management based on organization theory. In this context, the design will have to consider construction and modification of organizational structure to attain the organizational goal (Robbins; 1995). Stoner (1994; 508) has previously defined organizational redesign as "the process of selecting the needs of structure appropriately which highly determines its sustainability." So, it can be stated that redesigning in this context is modifying or reconstructing organizational structure to attain organizational goal based on the policy and 


\section{Macrothink}

the organizational environment (Robbins: 1995,7)

Based on the empirical experiment all this time, it is proven that redesigning organization in the bureaucracy context is never easy. This is so due to the approach used which is commonly formal and structural for organization management and its functions which is highly essential. However, it is harder to apply organization redesigning in the organization values to shape bureaucrats (referred to Jokowi as Mental Revolution).

The subsystem organization dimension based on the research is an organization structure which describes that the structure of Poverty Alleviation Program Organization in Kendari, especially TKPKD still refers to technical guideline of Poverty Alleviation Program.

The next analysis is correlated to the organization structure arrangement, in which the research interview highlights the fact that commonly organization structure arrangement is very complex because of the attempt to unify the existing main role and function of the organization. The research observation concludes that the main role and functions are arranged based on standard pattern of the technical guideline. Yet, it is not very flexible in dealing with Poverty Alleviation program. Even though each party in Kendari has understood his or her main role and functions related to his or her sustainability in the institution, when further analyzed regarding their working effectivity, there are some constraints and obstacles in carrying their main role and functions if they are mutated to other division.

\section{Poverty Alleviation Institutional Analysis}

Institutional analysis is carried out by describing the institution related to its readiness in poverty alleviation program through its competence and strategic compatibility with the goal of the organization.

To increase the competence, they conduct several strategies in the form of (1) participation, which is defined by related SKPD as citizen participation, (2) Self Support to help fasten problem solving, (3) Sustainable with the social organization pattern and (4) Partnership by building cooperation across different parties. 


\subsection{Socio-Cultural Relevance}

The duty of socio cultural team is well described in the following analogy

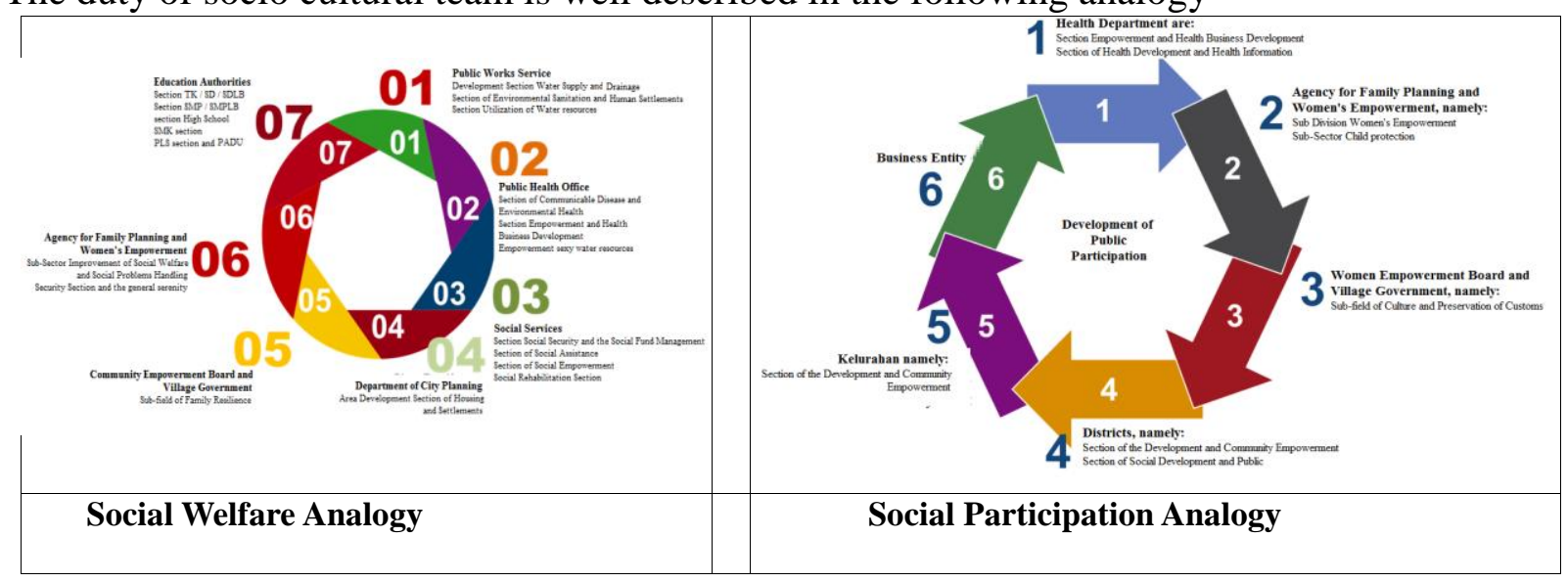

\section{Figure 2 Sub Social Field Relevance Analogy}

On the basis of both analogies, we can tell that socio cultural related institutions are handled by two subfields namely Social Welfare subfield and Social Participation Development subfield and that in the participation context is done by empowerment intervention (Tri Brata, 2015) For further explanation, please study the following figure.

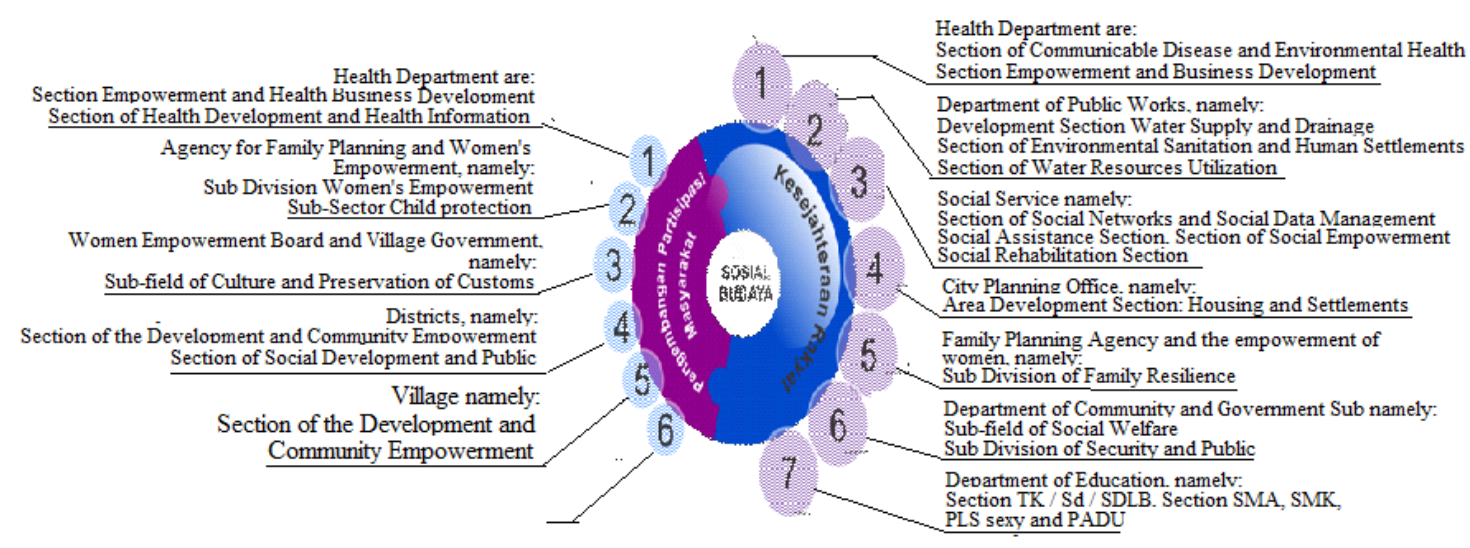

Figure 3 ; TKPKD Social Relevance Analogy 


\section{Macrothink}

\subsection{Economic Relevance}

The duty of of Economic Relevance Team, of democratic Economy subfield is described in the following analogy.

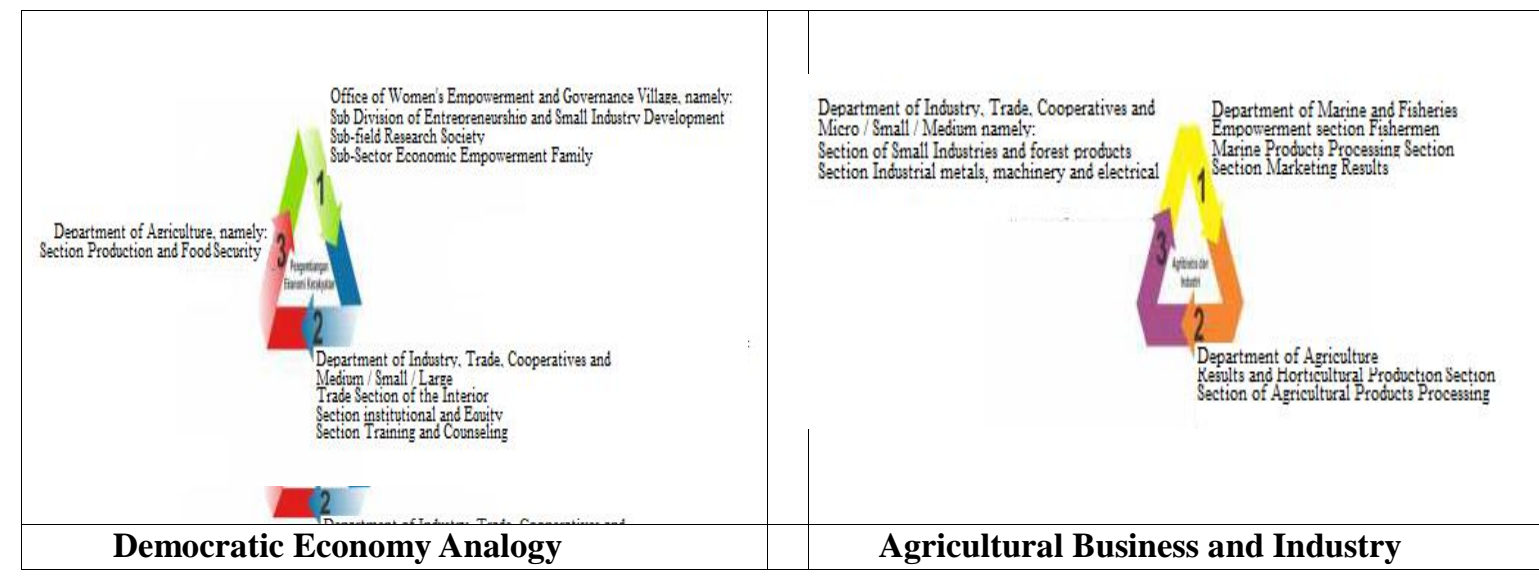

Figure 4 : Economic Sub Field Analogy

From both of the above analogies, we can tell that the economic related institutions are handled by two subfields namely Democratic Economy Subfield and Agricultural Bussiness and Industry. For Agricultural Bussiness and Industry, despite the fact that the main role and functions of the institution are not directly related, the activities of this subfield play an important role in poverty alleviation for the long term (the program has a long term effect). For further details, please study the following figure. 


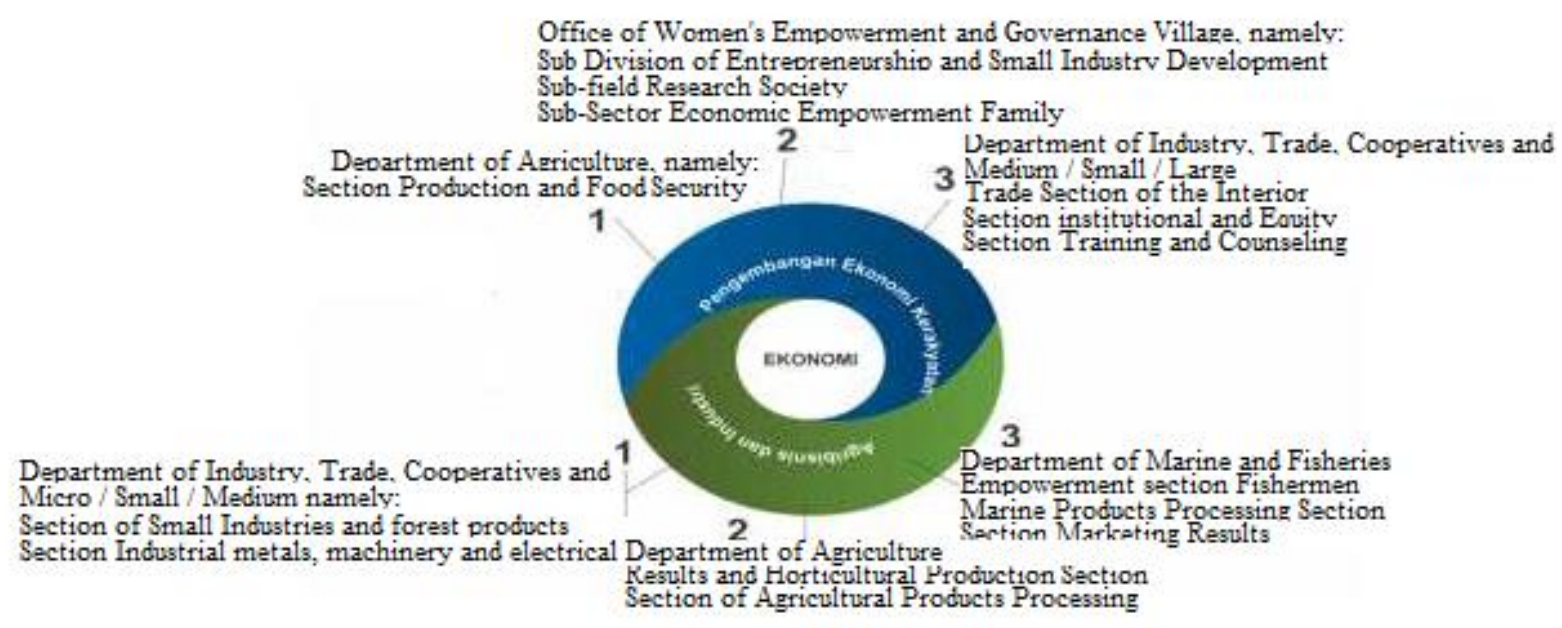

Figure 5 TKPKD Economic Relevance Analogy

\subsection{Facilities and Infrastructure Field Relevance}

The main duty of Poverty Alleviation Institution of Facilities and Infrastructure Field is very well described in the following analogy

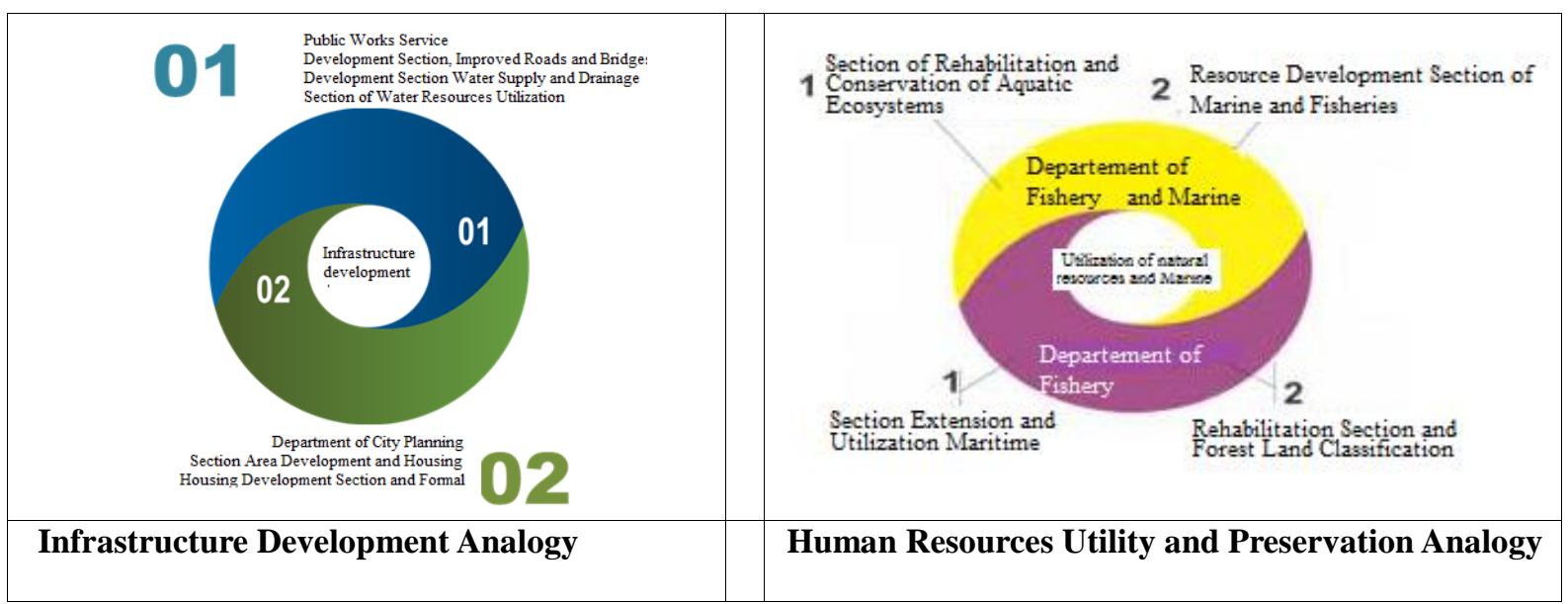

Figure 6 : Facilities and Infrastructure Field Analogy

Based on the previous analysis, we can tell that the Physical and Infrastructure related institutions are handled by two sub fields namely Infrastructure Development and Human Resources Utility and Preservation. For further explaination, please study the following figure. 


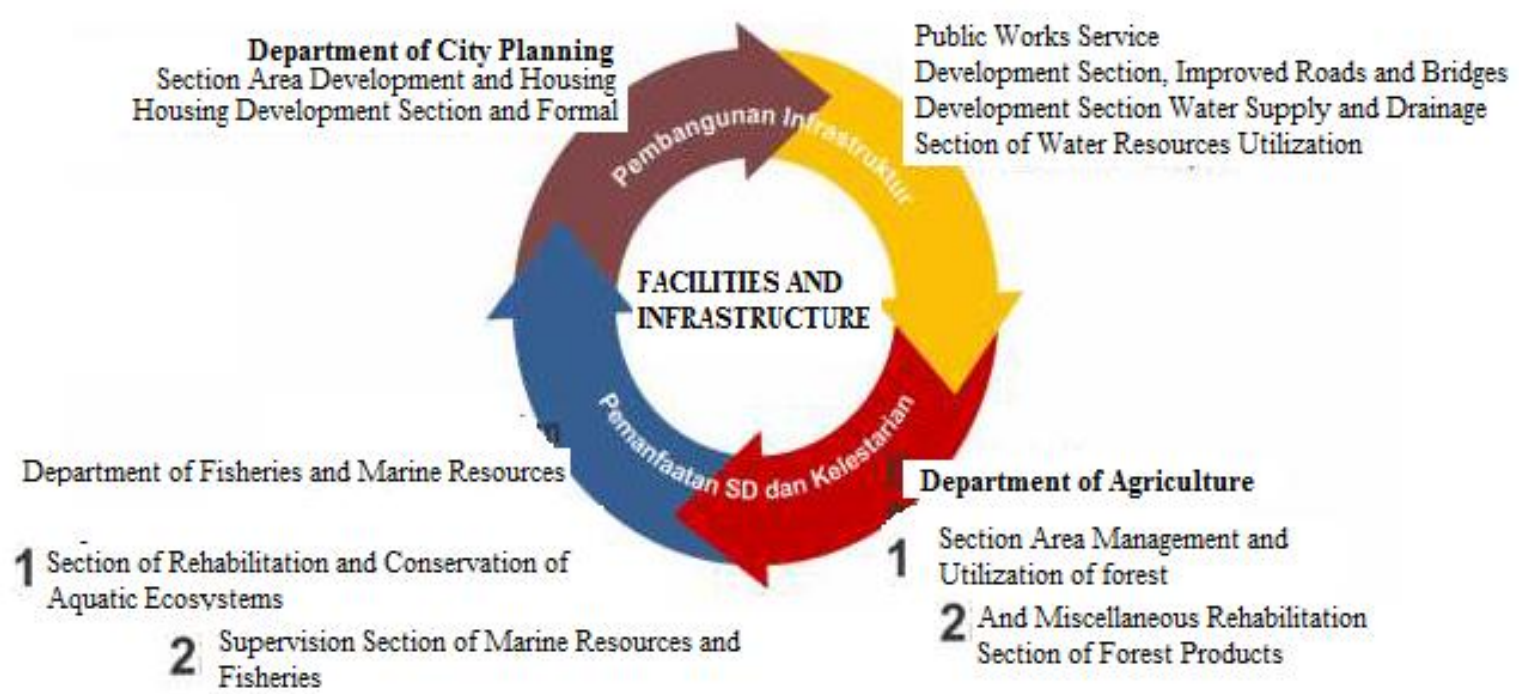

Figure 7 TKPKD Facilities and Infrastructure Relevance Analogy

\subsection{Government Cooperation Field Relevance}

The main role of Poverty Alleviation Institution of Government Cooperation is carried out by Cooperation and Development as described in the following analogy.

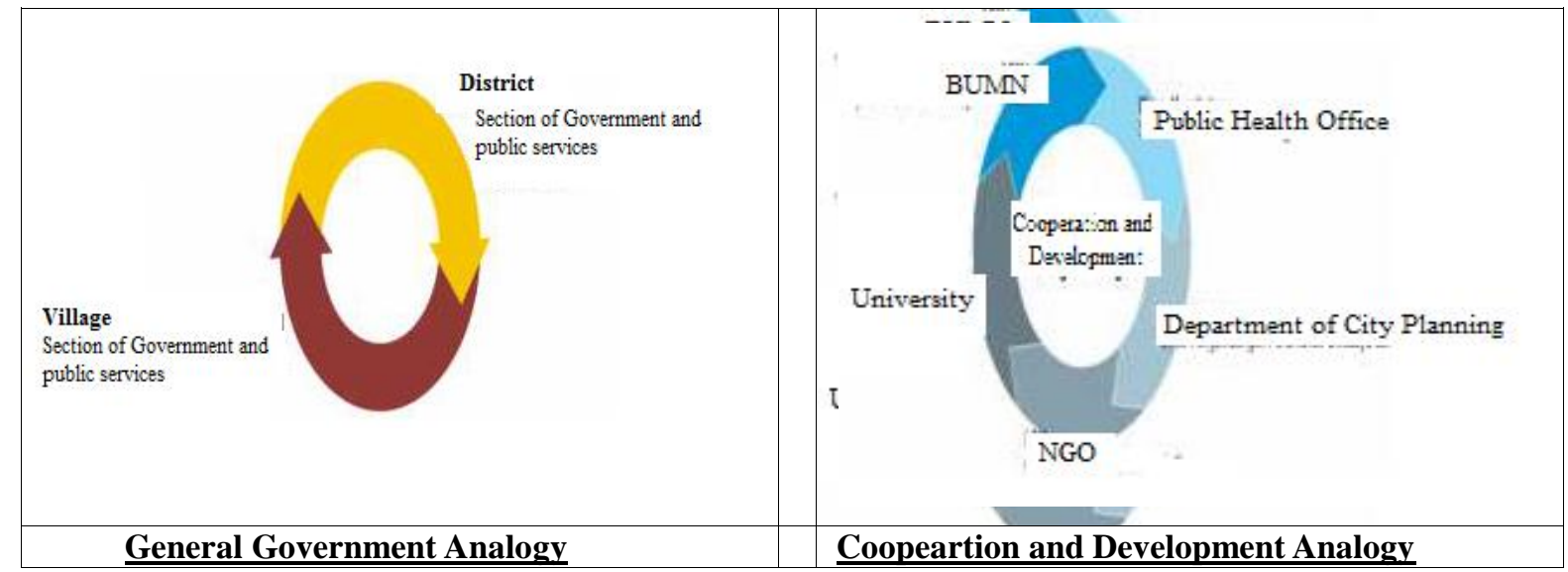

Figure 8 : Government Cooperation Analogy

On the basis of the previous explaination, we can tell that the Government Cooperation related Institutions are carried out by two subfields namely General Government and Cooperation and Development subfield. For further explaination, please study the figure below. 


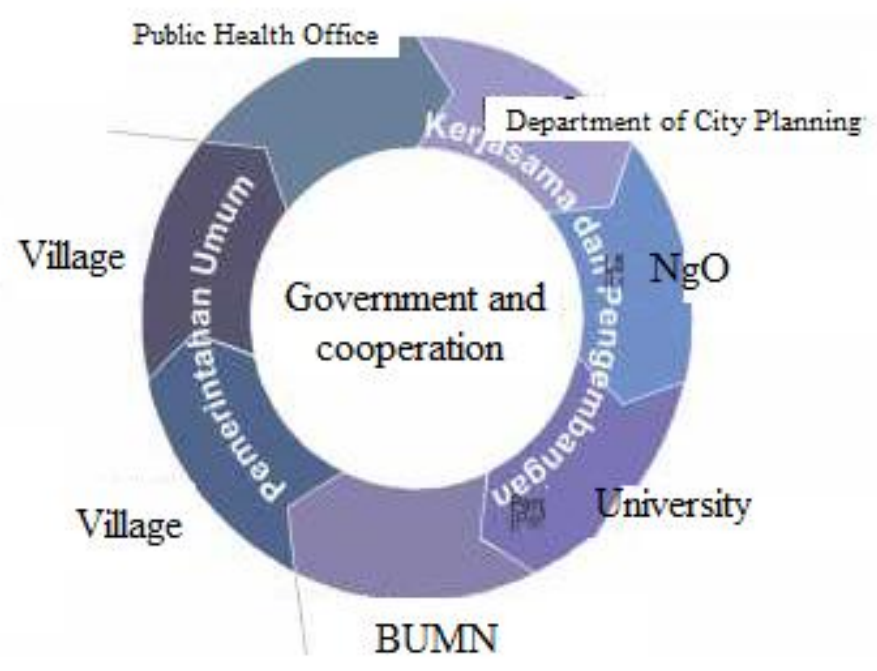

Figure 9 ; TKPKD Government Cooperation Relavance Analogy

Based on the general explanation above, we can assume that lcoal poverty alleviation (TKPKD) should divide its role into four sectoral institutions namely, Social, Economy, Facilities and Infrastructure, and Government Cooperation. For further detail, please study the following figure.

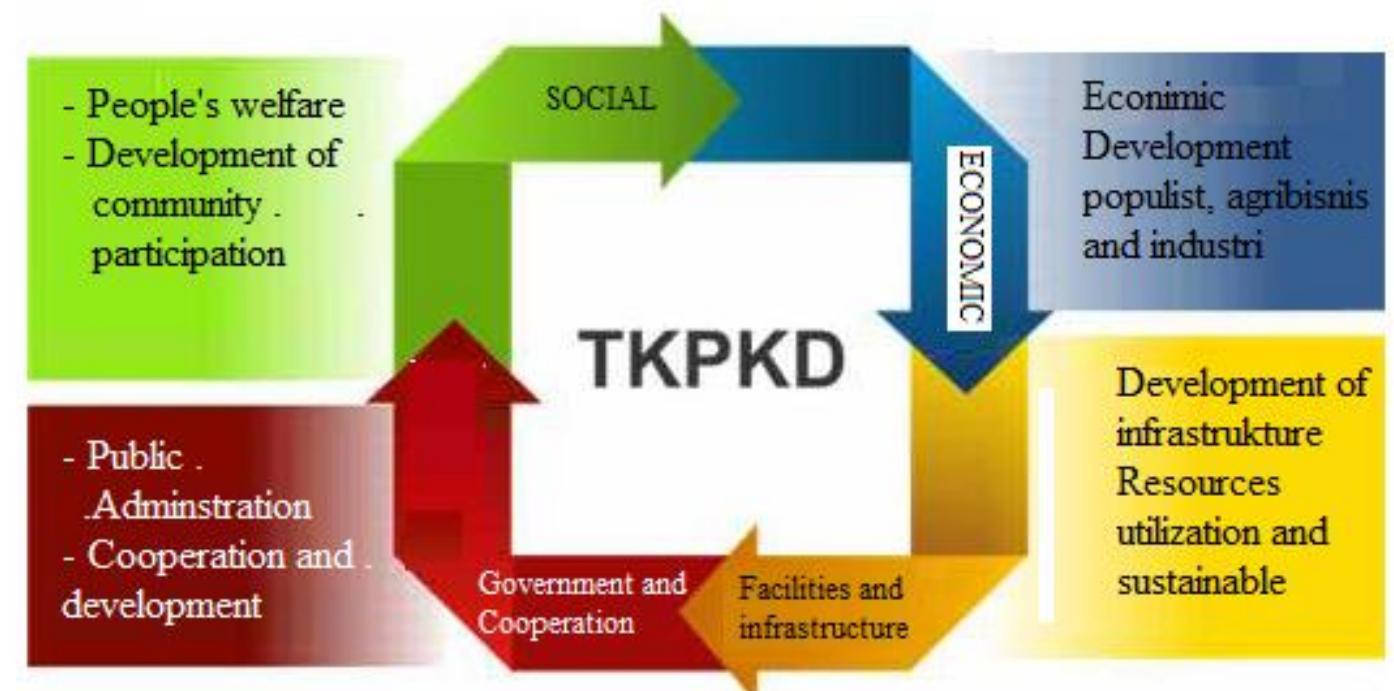

Figure 10 : Cross Sectoral Relevance Analogy of Poverty Alleviation

\section{Conclusion}

1. The practical implication of organization redesigning is carried out by preparing the organization through improving organization strategies which can be done by increasing organization competence and strategic compatibility with the program 
goals.

2. Organization model for organization redesigning of Poverty Alleviation assumes that the redesign has got to create organizational reconstruction into four sectors namely Social, Economy, Facilities and Infrastructure, and Government and Cooperation.

\section{Suggestions}

1. Since TKPKD is merely organizational setting, in order to apply new design of poverty alleviation organization we need to prepare the organization by improving organization strategies which can be done by optimizing four related fields to the Poverty Alleviation Program. Also we need to develop the organization competence and improve management by sharpening the organization vision and mission.

2. Related to program object, we need to strengthen the society by better understanding the values in order to make it sustainable.

3. To iimprove organization competence and adjust startegy with the program goals, we can apply structural redesign by improving and defining the main task and functions of all related parties, adjusting the cultural dimension with the underlying cultural values, and imroving organizational management characterstics.

\section{References}

Agussalim, 2009, Reduce Poverty; A New Proposal For Indonesia, in cooperation with Nala Cipta sustainable development management UNHAS. Makassar.

Djatnika, Dikcy Ustama, 2009, Role of Education in Poverty Alleviation, Jurnal Ilmu Administrasi Dan Kebijakan Publik (JIAKP), Vol. 6, No. 1, Januari

2009:1-12

Easton, David, 1953, The Political System, New York: Knopf, Frederickson, George H.2003. The State of Social Equity in American Public Administration . American Society for Public Administration-Vol.28 No.3- March 2005.http://www.aspanet.org/ scriptcontent/word/ Accomplishments 2005. doc

Goldsmith, Stephen and Donald F.Kettel (editor), (2009), Unlocking The Power Of Network: Keys To the Hight Performance Government, ash institute for Democratic governance and innovation John F. Kennedy School of Government Harvard University, Brookings institution press Washington, D.C.

Hamzah, Asiah, 2012. Policies Poverty And Hunger In Indonesia: Reality And Learning Organizations, Jurnal AKK, Vol 1 No 1, September 2012, hal 1-5 


\section{Macrothink}

Journal of Public Administration and Governance ISSN 2161-7104 2015, Vol. 5, No. 3

Kasmad, Rulinawaty (et all), 2015. Network Capacity Public Organization; A Study of Organizational Strengthening Integrated Empowerment In Implemnetasi street vendors in the city of Makassar, paper presented at the National Seminar IAPA, Makassar. 6-7 April 2015.ISBN 978-602-72434-0-8

Nurfadilah, 2015. Effectiveness Cooperation Indonesia - Usaid In Poverty Handling To Achieve MDGs by 2015, e-Journal of International Relations, 2015, 3 (1): 27-38. ISSN 0000-0000, ejournal.hi.fisip-unmul.org.@ Copyright 2015

Ramadhan, Syahril, 2015 Model-Based Innovation Collaboration In Baubau City, Paper presented at the National Seminar IAPA Sulselbar, 6-7 April 2015.

Robbins, Stephen P., 1995. Teori Organisasi: Struktur, Desain dan Aplikasi. Jakarta: Arcan. Sachs, Jeffrey D. 2005, Can Extreme Poverty be Eliminated, Scientific America Inc.

Stoner, James A.F dan Charles Wankel. (1988). Management: Third Edition Volume I.CV. Intermedia, Jakarta

Tribrata, Joko, (2014), The Organisation Network In Reduccing Poverty at Kendari City, IOSR ; Journal Of Humanitities and Social Sciense, Volume 19 Issu 1 Version-10, Feb-2014, PP 09-14, e-ISSN ; 2279-0837, p-ISSN ; 2279-0845

Tribrata, Joko, (2015), Network Concept Redesain of Organizations For Building Civil Society, Prociding Of Internastional Seminar, Democracy Election : Solution For Establising Good Governance, Makassar-Indonesia, March, 17-18,2015, ISBN, 978-602-921-01-9 